\title{
Contact points distribution according to the articulator type: Semiadjustable versus non adaptable versus digital
}

\author{
Distribuţia punctelor de contact în funcţie de tipul de articulator: \\ Semiadaptabil versus neadaptabil versus digital
}

\author{
Oana Almăşan'1, Smaranda Buduru', Simona lacob', Andreea Chisnoiu', Loredana Mițaru², \\ Mihai Mițaru², Maria Simona Dămăşaru³ ${ }^{3}$ Irina Grecu Mareşal ${ }^{4}$, Marius Negucioiu' \\ ${ }^{1}$ Universitatea de Medicină și Farmacie „Iuliu Hațieganu“, Cluj-Napoca, România \\ 2 Universitatea de Medicină și Farmacie „Lucian Blaga“, Sibiu, România \\ ${ }^{3}$ Ortodonţie, UMFST „G.E. Palade“, Tg Mureş, România \\ ${ }^{4}$ Ortodonţie şi Ortopedie dento-facială, St. Gallen, Germania
}

\begin{abstract}
Objectives. To analyze the location and intensity of occlusal contact points using three types of articulators: non adjustable, semiadjustable and digital with aiming at improving the diagnostic and treatment options in dental medicine. Material and method. For analyzing the distribution of contact points, the casts of a patient were mounted in the non adjustable and semiadjustable articulator. Intraoral scanning was performed using an intraoral scanner (Trios 3Shape) and reviewed in a virtual articulator. Occlusion obtained by the three methods was compared to the clinical situation.

Results. Contact points in maximum intercuspation, propulsion and lateral movements were analyzed. The points obtained by using the non adjustable articulator have been less intense and more unprecise. By digitizing the contact points, the image becomes more accurate and sharp.

Discussion. The semiadjustable articulator reproduces the contact points which are consistent with the clinical situation. Major differences occur when using the non adjustable articulator, which has a limited capacity of reproducing the clinical movements, therefore the marks are non consistent with the real clinical situation. The digital articulator seems promising in terms of eccentric movements.

Conclusions. However performing an articulator may be, the clinical maximum intercuspation will never be fittingly reproduced, due to the fact that articulators are rigid systems, whereas the oral cavity has an elasticity, resulting from the mandible, teeth and periodontal ligaments. Virtual articulators need to be further developed for more accurate results.
\end{abstract}

Keywords: articulator, occlusal contact points, intraoral scanning

\section{REZUMAT}

Obiective. Studiul a avut drept scop analiza localizării și distribuției punctelor de contact utilizând trei tipuri de articulatoare: nonajustabil, semiajustabil și digital, cu obiectivul de a îmbunătăți diagnosticul și planul de tratament în medicina dentară.

Material şi metodă. Pentru a analiza distribuția punctelor de contact, modelele unui pacient au fost montate întrun articulator semiajustabil și nonajustabil. Scanarea intraorală a fost efectuată utilizând un scaner intraoral (Trios 3Shape). Ocluzia obținută prin cele trei metode a fost comparată cu situația clinică.

Rezultate. Punctele de contact în intercuspidare maximă, propulsie și lateralitate au fost analizate. Punctele obținute cu ajutorul articulatorului nonadaptabil au fost mai puțin intense și mai imprecise. Prin digitalizare, punctele de contact au fost mai exacte si precise.

Discuții. Articulatorul semiajustabil reproduce punctele de contact care sunt în concordanță cu situația clinică. Diferente majore apar când se utilizează articulatorul nonajustabil, care are o capacitată limitată de a reproduce mișcările mandibulare, în consecință, marcajele sunt neconcordante cu situația clinică. Articulator virtual pare promitător în ceea ce privește mișcările excentrice.

Concluzii. Oricât ar fi de performant un articulator, nu se vor putea obține în poziția de intercuspidare maximă fix aceleași puncte de contact cu cele prezente în cavitatea orală, ca urmare a faptului că articulatoarele sunt sisteme rigide și cavitatea orală are o elasticitate care provine de la osul mandibular, dinți și parodonțiu. Articulatorul virtual trebuie să fie dezvoltat pe mai departe pentru a obține rezultate mai precise.

Cuvinte cheie: articulator, puncte de contact ocluzale, scaner intraoral 


\section{INTRODUCERE}

Articulatoarele reprezintă un subiect de cercetare actuală, ele fiind utilizate atât pentru stabilirea diagnosticului, cât și a planului de tratament. Articulatorul este un instrument care reproduce toate mişcările mandibulei (simulator) sau, mai precis, anumite condiţii mecanice ale acestor mişcări. Joseph Lejoyeux 1-a denumit ,,simulator al mişcărilor mandibulare“, iar autorii americani - ,simulator al sistemului stomatognat“". După Leibowitch, articulatorul este un ,manechin analog pacientului“" [1-4].

Montarea modelelor în articulator înaintea reabilitării planului ocluzal este fundamentală, deoarece de ea depind înălțimea cuspizilor și profunzimea șanţurilor și fosetelor și, implicit, succesul restaurării. Reproducerea cinematicii mandibulare, prin dezvoltarea de simulatoare ale sistemului stomatognat contribuie la prevenirea și tratamentul disfuncţiilor temporo-mandibulare. Articulatoarele nu au fost construite pentru a monta modelele conform unei analogii antropometrice, ci pentru a reproduce anumite mişcări ale mandibulei [5]. Tratamentul protetic este menit să creeze un relief ocluzal care să asigure o ocluzie statică și dinamică echilibrată și o relație mandibulo-craniană stabilă, consolidând în felul acesta efectul terapiei de echilibrare ocluzală, de relaxare musculară și repoziționare mandibulară. Orice reabilitare incorectă care influenţează buna funcționare a ocluziei poate provoca modificări patologice la nivelul întregului sistem stomatognat. Schultz susţine că „disfuncţiile temporo-mandibulare nu pot apărea fără o anume stare de tensiune nervoasă, chiar dacă sunt prezenţi factori patologici de altă natură“ [6].

Ocluzia clinică trebuie să fie cât mai concordantă cu cu ocluzia obținută prin intermediul simulatoarelor, indiferent de tipul acestora: convenționale sau digitale [7-10]. Am ales această comparație deoarece în practica curentă se mai folosesc articulatoare neadaptabile, care nu respectă arcul de închidere și deschidere mandibulară; articulatoarele semiadaptabile sunt utilizate frecvent, având o acuratețe crescută. Tehnica digitală este promițătoare, având însă un preț crescut.

\section{OBIECTIVE}

Obiectivele acestui studiu au fost de a analiza distribuţia punctelor de contact ca localizare și in- tensitate utilizând cele trei tipuri de simulatoare (neadaptabil, semiadaptabil și digital) și comparația acestora cu ocluzia statică clinică în zona laterală şi frontală în intercuspidare maximă şi ocluzia dinamică în propulsie și lateralitate. S-a analizat precizia articulatoarelor neadaptabile, semiadaptabile sau digitale asupra distribuției punctelor de contact și compararea acestora cu situația clinică, cu scopul de a îmbunătăți performanțele diagnostice și terapeutice în medicina dentară.

\section{MATERIAL ŞI METODE}

Pentru a analiza distribuția punctelor de contact, s-a realizat montarea modelelor unui pacient atât în articulatorul neadaptabil, cât și cel semiadaptabil. S-a efectuat scanarea intraorală a arcadelor dentare și ocluziei statice și dinamice utilizând un scaner intraoral (Trios 3, 3Shape). În final, s-a realizat comparația ocluziei obținute prin cele trei metode cu situația clinică.

În acest scop, s-a utilizat un articulator neadaptabil cu valori medii, A-HU, și un articulator semiadaptabil, BIO-ART A7, Plus împreună cu arcul facial ELITE de la BIO-ART. Analiza digitală s-a realizat în ajutorul programului Denta Designer, 3Shape.

Amprenta arcadelor dentare s-a obținut cu ajutorul unui silicon de adiție (Express ${ }^{\mathrm{TM}}$ XT Putty Quick și Express ${ }^{\text {TM }}$ Regular Body), acesta prezentând fidelitate și stabilitate bună în portamprente standard din metal cu perforații. Portamprenta a fost pensulată cu adeziv (VPS TRAY Adeshive de la 3M ESPE) cu aproximativ 10 minute înainte de luarea amprentei). S-a dozat în cantităţi egale siliconul de adiţie de consistenţă crescută Express ${ }^{\mathrm{TM}}$ XT Putty Quick și s-a mixat, apoi s-a încărcat portamprenta cu materialul pregătit. Concomitent cu această manoperă, s-a injectat silicon de adiție de consistență redusă cu ajutorul pistolului la nivelul arcadelor și la nivelul zonelor retentive și s-a aplicat silicon fluid și peste siliconul de consistenţă crescută care a fost încărcat în portamprentă. Modelele de lucru s-au realizat din gips extra dur GC Fujirock, GC.

Pentru programarea condiliană, valorile unghiurilor Bennett și ale pantei condiliene s-au obținut cu ajutorul axiografului computerizat $\mathrm{Ca}-$ diax ${ }^{\circledR}$ Compact 2 System, Gamma Dental Softwa-

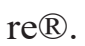


Montarea modelelor în articulatorul neadaptabil a fost făcută aleator, uilizând parametrii condilieni standard. Montarea modelelor în articulatorul semiadaptabil s-a făcut pe baza înregistrării cu arcul facial și programarea sa pe baza axiografiei computerizate. În cazul analizei digitale, modelele au fost plasate arbitrar în articulatorul virtual (conform posibilităţilor software-ului programului de design), dar cu utilizarea parametrilor condilieni obținuți prin axiografia computerizată.

\section{REZULTATE}

Rapoartele ocluzale în poziția de intercuspidare maximă sunt redate în figura 1 .

În poziția de intercuspidare maximă, clinic s-au obținut următoarele puncte de contact, plasate la arcada maxilară la nivelul dinților 1.1, 1.2, 1.3, $1.4,1.6,2.1,2.2,2.3,2.5,2.6,2.7$ și la mandibulă la nivelul dinților 3.1, 3.2, 3.3, 3.5, 3.7, 4.1, 4.2, 4.3, 4.4, 4.5, 4.7 (Fig. 2).

În mișcarea de propulsie s-au obținut la arcada maxilară trasee pe dinții 1.1, 1.2, 1.3 de intensități diferite, cu 1.1 interferență activă, 2.1 2.2, 2.3, și 1.4 și 2.4 interferențe pasive (Fig. 3).

Punctele de contact obținute cu ajutorul articulatorului neadaptabil sunt redate în figura 4 .

Se observă o distribuție mai puțin intensă cu localizare mai imprecisă.

Punctele de contact în poziţia de intercuspidare maximă pe articulatorul semiadaptabil sunt redate în figura 5 .

Punctele de contact în ocluzia dinamică pe articulatorul semiadaptabil sunt redate în figura 6 .

În urma mișcării de lateralitate stângă (Fig. 6 b), s-a determinat clinic un ghidaj antero-lateral, cu implicare canină mai intensă și cu interferențe active la nivelul dinților 2.4, 2.7 la nivelul versantelor interne ale cuspizilor vestibulari.

În urma mișcării de lateralitate dreaptă (Fig. 6 c), s-a obținut clinic ghidaj antero-lateral, cu interferențe active la nivelul dinților 1.1, 1.6, versant intern cuspid palatinal și 4.7 cuspid disto-vestibular, versant intern.

Punctele de contact în ocluzie analizate cu ajutorul scanerului intraoral sunt redate în figura 7 .
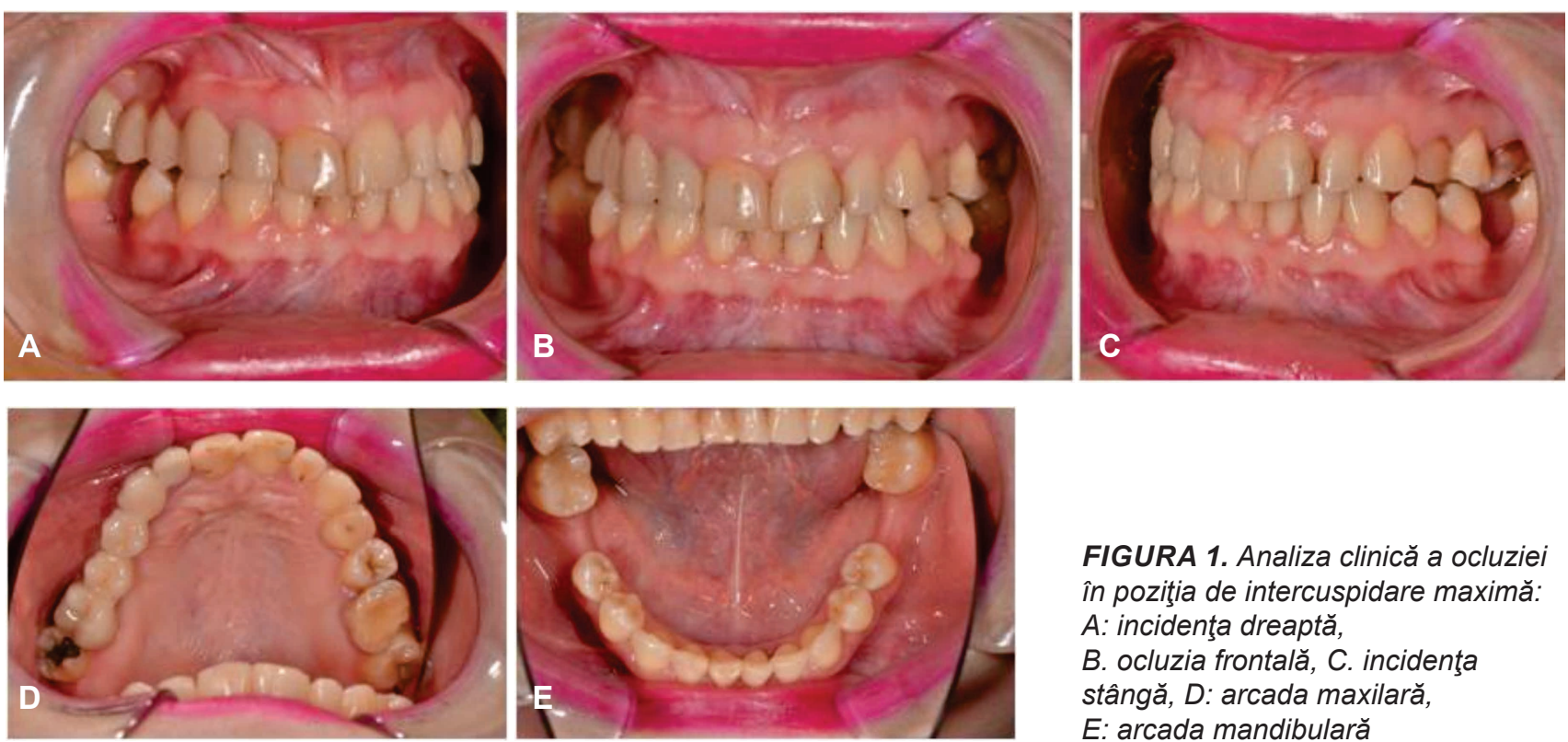

FIGURA 1. Analiza clinică a ocluziei în poziţia de intercuspidare maximă: A: incidenţa dreaptă, $B$. ocluzia frontală, C. incidenţa stângă, D: arcada maxilară, E: arcada mandibulară
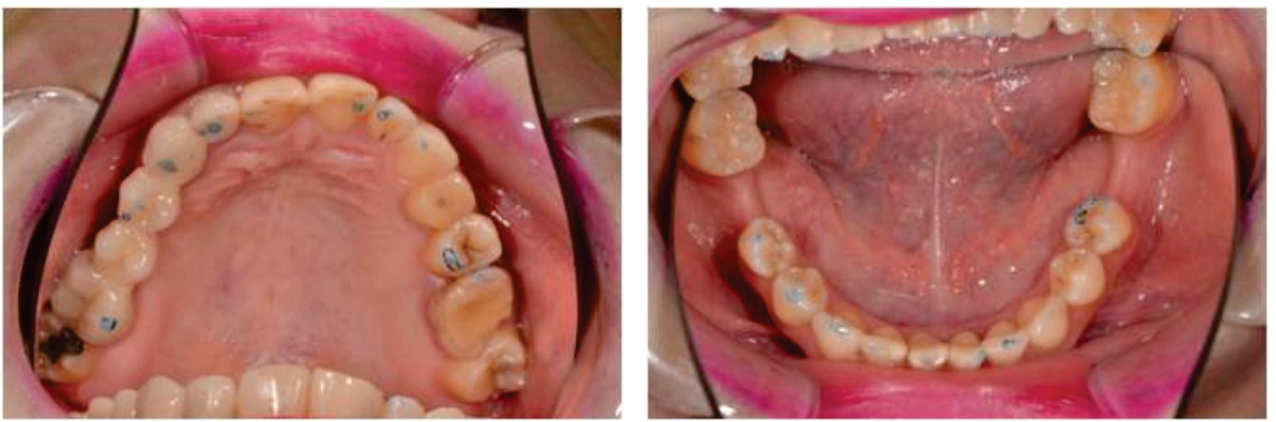


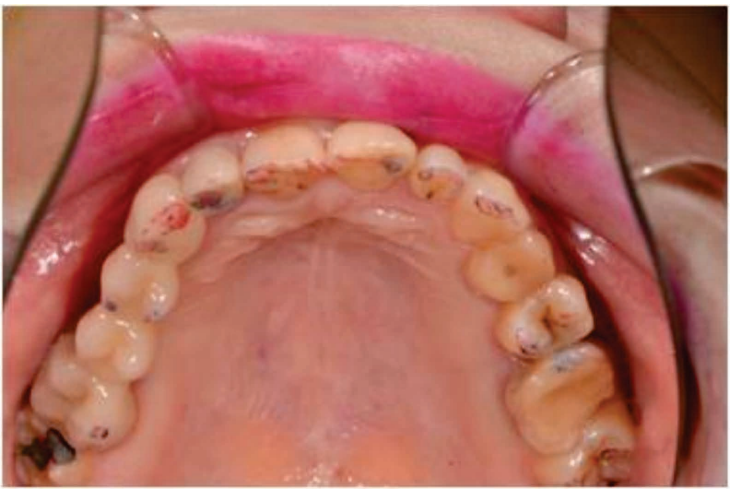

FIGURA 3. Analiza traseelor de ghidaj în ocluzia dinamică: propulsie
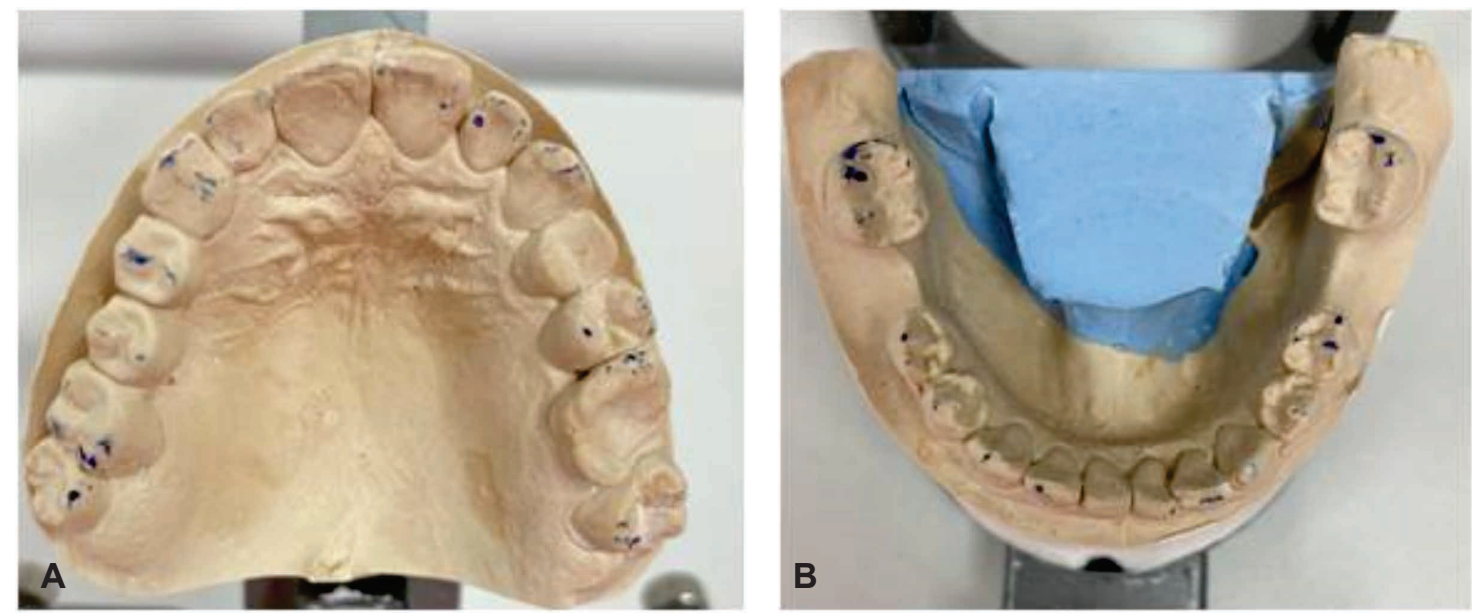

FIGURA 4. Punctele de contact în poziţia de intercuspidare maximă obţinute cu ajutorul articulatorului neadaptabil: A. maxilar, B. mandibula
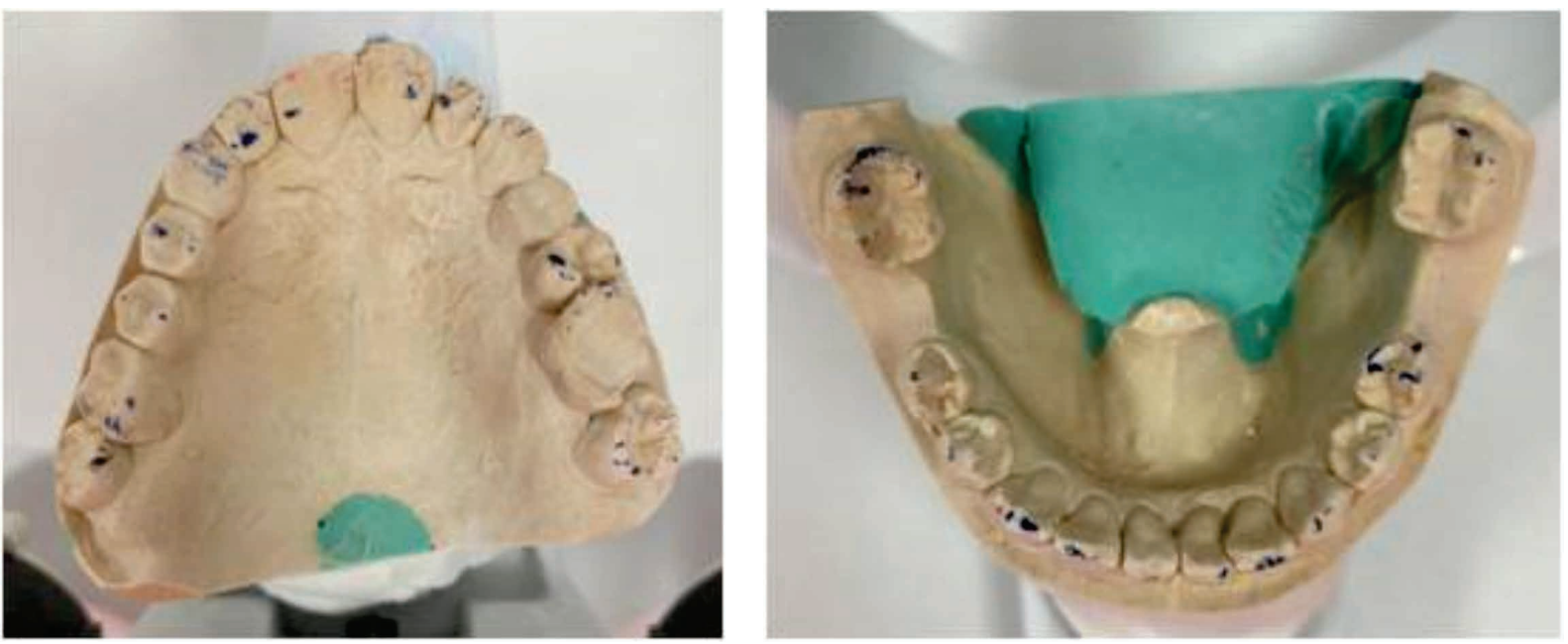

FIGURA 5. Punctele de contact în poziţia de intercuspidare maximă pe articulatorul semiadaptabil

Se observă faptul că prin digitalizarea punctelor de contact imaginea are o acuratețe crescută și o precizie ridicată. Faţă de situaţia din cavitatea orală, se observă că la nivelul dintelui 1.1 este prezent un punct de contact de intensitate crescută la nivelul crestelor meziale și distale de smalț. La nivelul dinților $1.2,1.3$, sunt vizibile punct de contact la nivelul crestei meziale care nu apar marcate la nivelul cavității orale. La nivelul dintelui 1.4, cuspid vestibular, versant intern, este prezent clinic un punct de contact care nu apare marcat prin tehnologia digitală. La nivelul dintelui 1.6, cuspid palatinal, prin scanare punctul de contact are o intensitate crescută și o zonă de marcaj mărită. La nivelul 

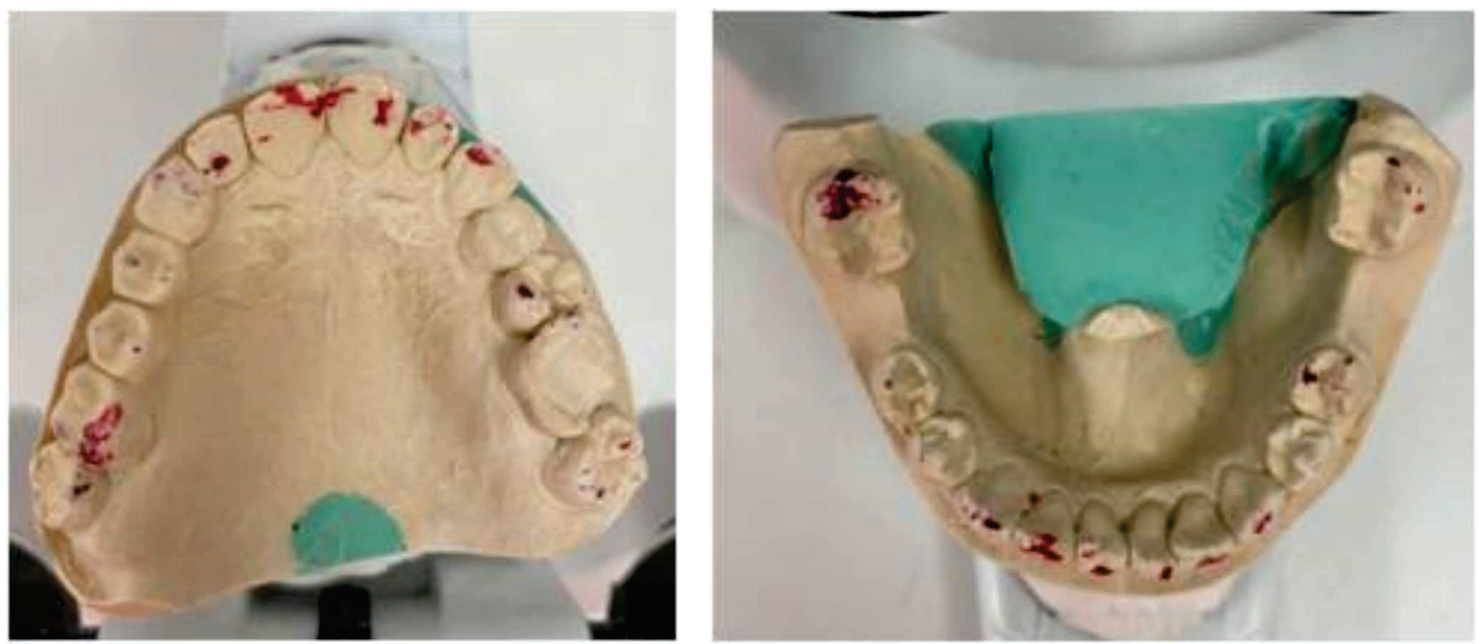

FIGURA 6A. Propulsie
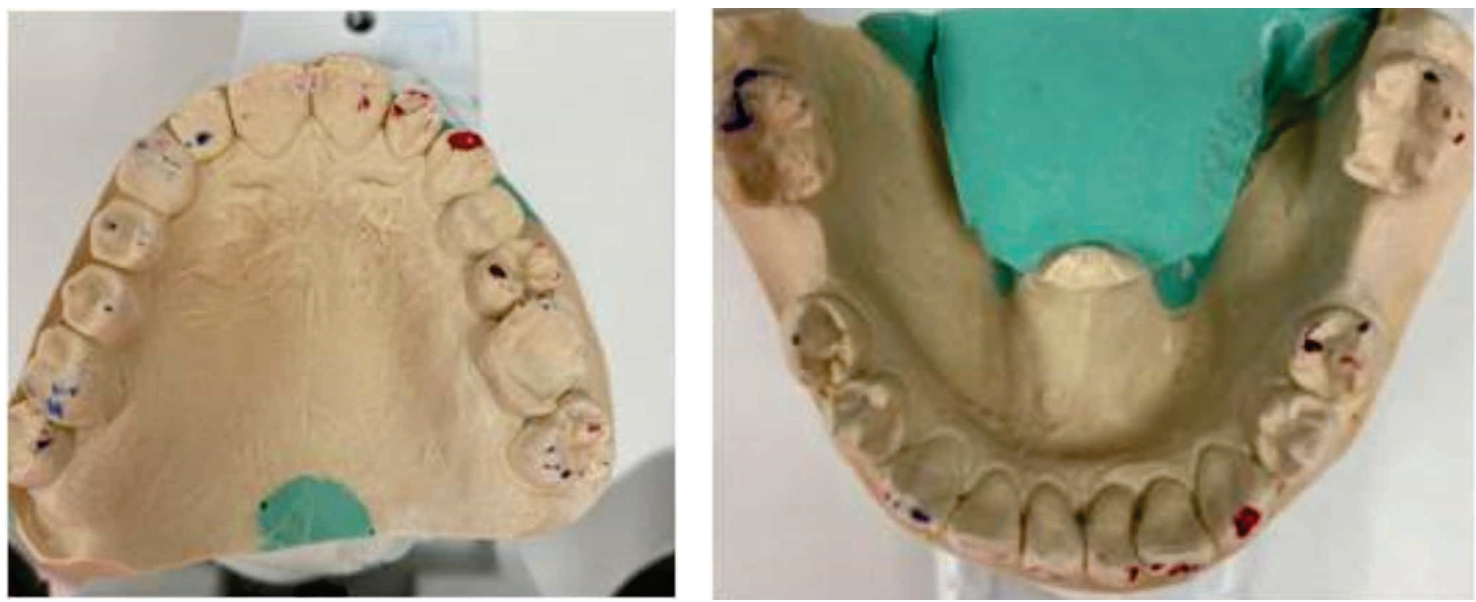

FIGURA 6B. Lateralitate stânga
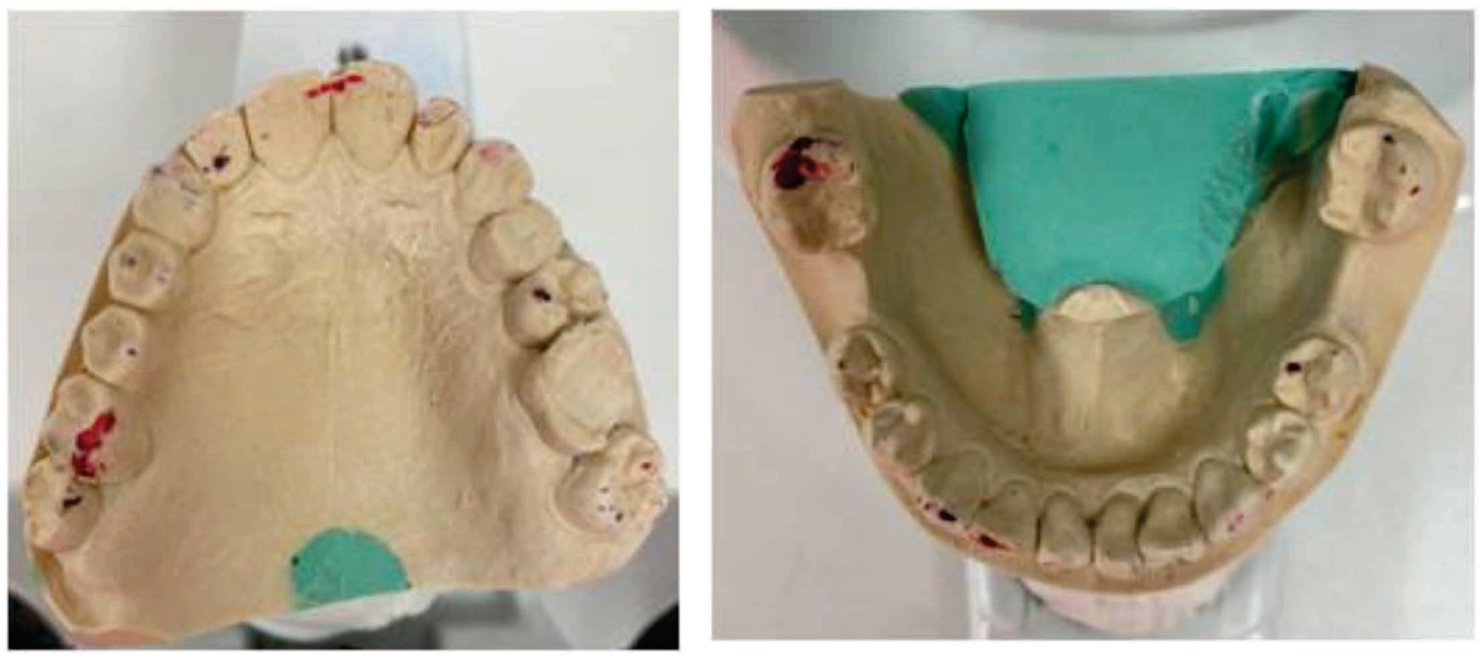

FIGURA 6C. Lateralitate dreapta

dintelui 1.7 , cuspid palatinal, panta mezială, apare marcat un punct de contact care clinic nu a fost prezent. Intensitatea punctelor de contact de la nivelul dinţilor 2.1, 2.2, 2.3 este marcată mai intens prin scanare față de situația clinică. Punctul de contact de la nivelul dintelui 2.6, creasta marginală mezială nu este redat prin scanare. Punctele de contact de la nivelul dinților 3.1, 3.2, 3.3, marginea incizală, au o intensitate crescută la analiza digitală, iar punctul de contact de la nivelul vârfului cus- 

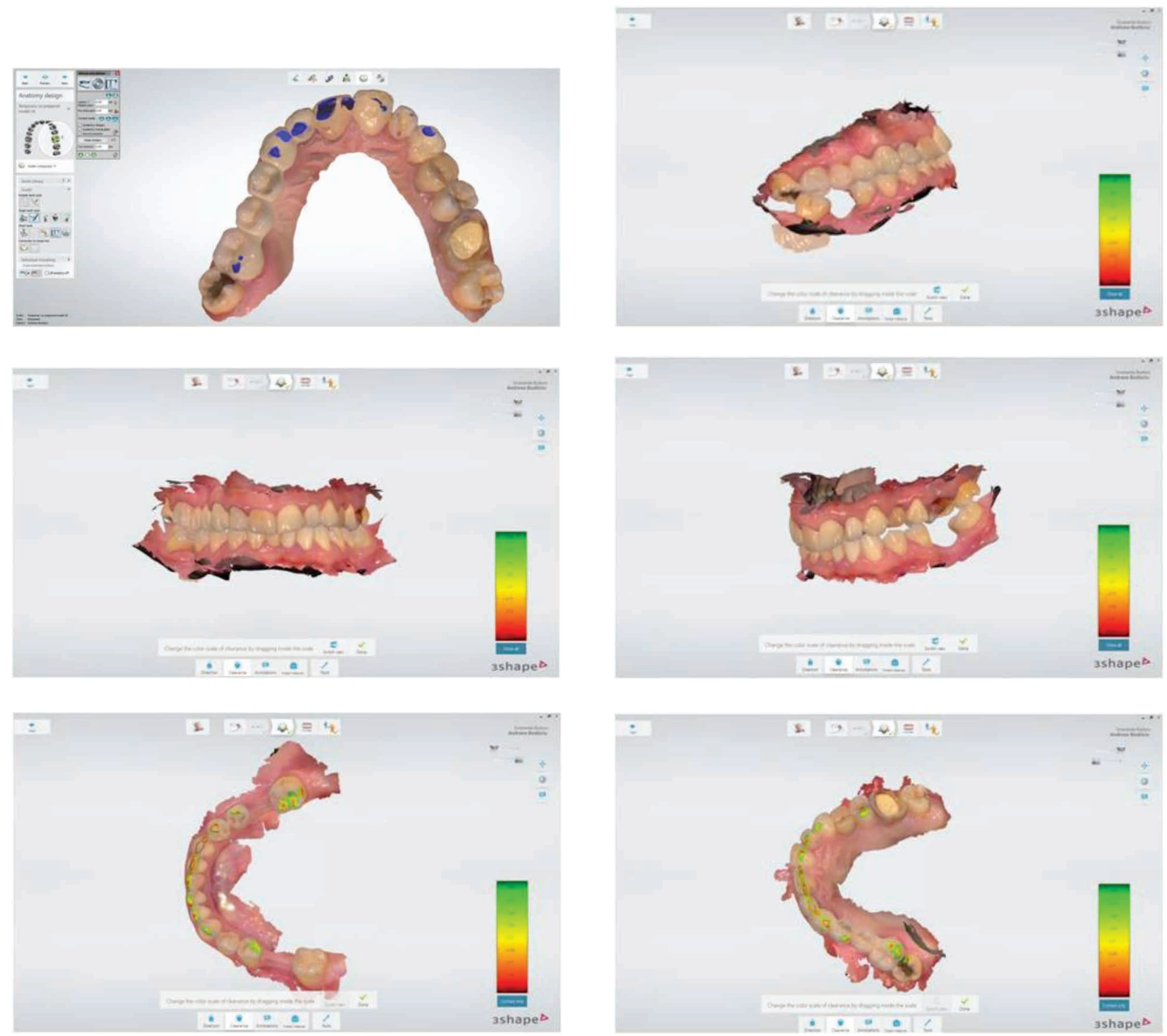

FIGURA 7. Analiza ocluziei utilizând scanerul intraoral Trios 3Shape

pidului 3.3 clinic are un marcaj fin, care la scanare are o intensitate crescută. Punctul de contact de la nivelul vârfului cuspidului disto-vestibular al dintelui $3.7 \mathrm{nu}$ apare marcat la scanare. Intensitatea punctelor de contact de la nivelul marginii incizale a dinților 4.1, 4.2 este crescută la scanare față de situația clinică. La nivelul dintelui 4.7, harta punctelor de contact are o suprafață mărită și o intensitate crescută față de marcajul obținut clinic cu hârtie de articulație, la nivelul dintelui 4.7, cuspid mezio-lingual, versant intern.

\section{DISCUŢII}

Utilizând articulatorul semiadaptabil, analiza punctelor de contact este concordantă cu situația clinică a arcadelor dentare, însă există diferențe majore față de utilizarea articulatorului neadaptabil, la care distribuția este diferită. Articulatorul neadaptabil prezintă o capacitate limitată în a realiza mișcările, astfel marcajul punctelor nu este concordant cu situația clinică reală [11-14].

Studiile anatomice efectuate de către Bonwill au arătat că distanța intercondiliană medie este de $110 \mathrm{~mm}$. Majoritatea articulatoarelor semiadaptabile au acest parametru setat la aproximativ această valoare. Din cauza geometriei implicate în mișcarea mandibulară, acest parametru are un impact relativ mic asupra preciziei restaurării finale. Panta condiliană este un parametru important în restaurarea ocluzală fără interferențe, deși majoritatea pacienților prezintă o înclinație mai mare de 
$40^{\circ}$, în practică se întâlnesc pacienți cu panta condiliană mai mică de $40^{\circ}$, de aceea este foarte important a se utiliza un articulator adaptabil astfel încât să fie reglat și individualizat în funcție de parametrii înregistrați la fiecare pacient în parte.

Utilizarea unui arc facial permite înregistrarea tridimensională exactă a poziției maxilarului față de baza craniului, iar aceasta este motivația cea mai convingătoare pentru a utiliza articulatorul semiadaptabil.

Obiectivul principal al articulatoarelor este acela de a reproduce cât mai fidel mișcările complexe mandibulare față de maxilar și baza craniului, întrun raport cât mai aproape de natural al modelelor de studiu. Pentru programarea cât mai exactă a articulatoarelor și stabilirea unor rapoarte spațiale corecte ale poziției arcadei maxilare în raport $\mathrm{cu}$ articulația temporo-mandibulară, este necesară reperarea poziţiei axei balama, a punctului suborbitar și distanţa dintre ele și unele repere ocluzale.

Pentru analiza comparativă a distribuției punctelor de contact în articulatorul neadaptabil, am montat modelele și în articulatorul cu valori fixe.

Acest articulator prezintă o înclinare a pantelor articulare de $30^{\circ}$, fără a prezenta posibilitatea de reglare a unghiului Bennett şi a altor constante ale mişcării mandibulare. Singurul parametru reglabil este ghidajul incisiv, variabil prin intermediul unui platou cu angularea gradată. Axa bicondiliană este reprezentată de o tijă, iar rotaţia se face pe pantele de $30^{\circ}$ amintite, aflate într-o poziţie postero-inferioară axei bicondiliene conform teoriei centrelor instantanee de rotaţie a lui Gysi [15].

Aceste articulatoare reproduc mişcările de deschidere-închidere, propulsie, lateralitate. Faţă de articulatorul semiadaptabil la care se montează mai întâi modelul superior, la acesta se montează modelul inferior prima dată [16]. Modelele trebuie montate cu dinții în contact în poziția ocluzală dorită. Dacă între arcade este plasată o ceară de înregistrare cu grosime mare care determină o poziție depărtată a arcadelor, ulterior va apărea o modificare a poziţiei de intercuspidare maximă prin apropierea brațelor articulatorului. Aceasta se întâmplă deoarece axa de rotație balama de închidere a gurii pacientului nu corespunde cu axa balama a aparatului $[17,18]$.

Articulatorul semiadaptabil BIO-ART A7 Plus prezintă un mecanism de manipulare simplu, ceea ce îl face util în toate situațiile de reabilitări oclu- zale. Permite reproducerea mecanică și exactă a mișcărilor fundamentale ale mandibulei (lateralitate și propulsie) cu posibilitatea reglării prin valori a pantei condiliene și a unghiului Benett.

În cele mai multe cazuri în care nu se utilizează arcul facial și articulatorul semiadaptabil, în momentul probei lucrării protetice în cavitatea orală este nevoie de multiple ajustări, iar astfel va rezulta o morfologie atenuată și ineficientă a restaurării.

În cazul utilizării tehnologiei digitale, se observă discrepanțe în ceea ce privește distribuția și intensitatea punctelor de contact în intercuspidare maximă şi a bună concordanţă a ghidatelor. Acest lucru se datorează lipsei unui arc facial virtual care implică o plasare aleatorie a modelelor virtuale, dar programarea cu parametrii condilieni specifici pacientului implică o bună reproducere a mișcărilor excentrice $[19,20]$.

Adoptarea unor noi proceduri și echipamente necesită o investiție iniţială în timp și tehnologie. Pentru a avea sens acest deziderat, trebuie să existe dovezi clare cu privire la beneficii și avantaje, astfel utilizarea tehnologiei digitale conferă un aport crescut al economiei de timp, precizie ridicată a viitoarelor lucrări protetice, acuratețe crescută a restaurărilor.

\section{CONCLUZII}

Analizând comparativ în cele trei variante (articulatorul semiadaptabil, neadaptabil și digital) am constat că între situația clinică din cavitatea orală și analiza realizată pe articulatorul semiadaptabil și tehnologia digitală nu au existat diferențe majore în distribuția punctelor de contact, dar între situaţia clinică și articulatorul neadaptabil diferențele au fost importante.

Oricât de performant ar fi un articulator, nu se vor putea obține în poziția de intercuspidare maximă identic aceleași puncte de contact cu cele prezente în cavitatea orală, ca urmare a faptului că articulatoarele sunt sisteme rigide și cavitatea orală are o elasticitate care provine din elasticitatea osului mandibular care se flectează, elasticitatea dinților în os prin ligamentele parodontale și elasticitatea țesuturilor articulare. Pentru ca un articulator să prezinte acuratețe, este necesar să fie cât mai ajustabil, diferențele între aceste elemente să fie cât mai mici şi locul unde se întâlnesc punctele de contact să fie cât mai apropiat, astfel încât vii- 
toarele lucrări protetice să reproducă fidel situația din cavitatea orală. Articulatorul virtual necesită dezvoltarea unor metode de transfer a modelelor virtuale printr-un arc facial virtual.

\section{BIBLIOGRAFIE}

1. Ramfjord SP, Ash MM. Occlusion (3rd Edition). WB Saunders, Philadelphia, 1983.

2. Ash MM, Ramfjord SP. Manuel d'occlusion pratique. Edition Masson, 1984.

3. Ash MM, Ramfjord SP. Occlusion (4th Edition). WB Saunders, Philadelphia, 1995

4. Fowler J, Tamura K. Essential of Dental Technology. Quintessence, 1987.

5. Marguelles-Bonnet R, Young JP. Pratique de l'analyse occlusale et de l'equilbration. Paris: Editions CdP, 1984.

6. Schulz D, Winzen O. Von der Behandlungsplanung zur natur- und funktionsgerechten Rekonstruktion. Frankfurt: Dental Spectrum, 1997.

7. Tan MY, Ung JY, Low AH, Tan EE, Tan KB. Three-dimensional repositioning accuracy of semiadjustable articulator cast mounting systems. J Prosthet Dent. 2014 Oct;112(4):932-41.

8. Thompson GA, Nick C, Francisco P, Lux L, Wiens JP. Comparison of two arbitrary cast transfer systems with a kinematic facebow for mounting a maxillary cast on a semiadjustable articulator. J Prosthet Dent. 2021 Mar 15:S0022-3913(21)00002-0.

9. Buduru S, Finta E, Almasan O, Fluerasu M, Manziuc M, lacob S, Culcitchi C, Negucioiu M. Clinical occlusion analysis versus semi-adjustable articulator and virtual articulator occlusion analysis. Med Pharm Rep. 2020 Jul;93(3):292-296.

10. Lepidi L, Galli M, Mastrangelo F, Venezia P, Joda T, Wang HL, Li J. Virtual Articulators and Virtual Mounting Procedures: Where Do We Stand? J Prosthodont. 2021 Jan;30(1):24-35.

\section{Notă}

Toți autorii au avut contribuție egală la publicarea acestui material.

Conflict of interest: none declared Financial support: none declared

11. Joshi PR, Bhat GS, Dixit S. Selection of articulator for general dental practice. Kathmandu University Medical Journal. 2008;6(1):112-116.

12. Hochman N, Ehrlich J, Yaffe A. Tooth contact during dynamic lateral excursion in young adults. J Oral Rehabil. 1995;22(3): 221-4.

13. Yaffe A, Ehrlich J. The functional range of tooth contact in lateral gliding movements. J Prosthet Dent. 1987;57(6):730-3.

14. Dawson PE. Position paper regarding diagnosis, management, and treatment of temporomandibular disorders. The American Equilibration Society. J Prosthet Dent. 1999;81(2):174-8.

15. Bratu $D$, Țuculescu SU. Amprenta și modelul în protezarea fixă. Timișoara: Editura Signata, 2001.

16. Awni R. Classification of articulators. J Prosthet Dent. 1980; 43(3):344-347.

17. Baciu S, Alb C, Alb F, Manole M. Tehnologia protezelor unidentare. Cluj-Napoca: Editura Alma Mater, 2007.

18. Buduru S, Almășan O. Noțiuni practice de ocluzologie. Cluj Napoca: Editura Napoca Star, 2010.

19. Úry $E$, Fornai $C$, Weber GW. Accuracy of transferring analog dental casts to a virtual articulator. J Prosthet Dent. 2020 Feb; 123(2):305-313.

20. Maestre-Ferrín L, Romero-Millán J, Peñarrocha-Oltra D, Peñarrocha-Diago M. Virtual articulator for the analysis of dental occlusion: an update. Med Oral Patol Oral Cir Bucal. 2012; 17(1):e160-3. 